\title{
Impact of Teaching Academic Text Cohesive Devices on ESL Undergraduates' Listening Comprehension
}

\author{
Mohammad Nasim Tahsildar \\ Centre for Modern Languages \& Human Sciences, Universiti Malaysia Pahang \\ Lebuhraya Tun Razak, 26300 Gambang, Pahang, Malaysia \\ Tel: 609-549-3051Ｅ-mail: nasim83.angel@gmail.com \\ Zailin Shah Yusoff (Corresponding author) \\ Centre for Modern Languages \& Human Sciences, Universiti Malaysia Pahang \\ Lebuhraya Tun Razak, 26300 Gambang, Pahang, Malaysia
}

Tel: 609-549-3051Ｅ-mail: zailinshah@ump.edu.my

Received: August 21, 2014 Accepted: September 3, 2014 Published: September 3, 2014

doi:10.5296/ijele.v2i2.6266 URL: http://dx.doi.org/10.5296/ijele.v2i2.6266

\begin{abstract}
This paper reports on a study investigating the effects of teaching academic text cohesive devices on ESL students' listening comprehension. The main objective of the study was to find out if through teaching cohesive devices would enhance students' prior knowledge and subsequently result in increased listening comprehension. Based on a pre-test post-test research design, 40 students enrolled in English for Academic Purposes course at a university in Malaysia were engaged as participants. A listening comprehension test was conducted prior to and post-intervention. The intervention consisted of lessons on academic text cohesive devices. The data were then analysed and reported using descriptive statistics and paired samples t-test. From the findings, it was clear that there was an increase in the minimum and maximum scores as well as in the mean scores between the pre- and post-test scores. More importantly, there was evidently a significant improvement in the participants' post-test listening comprehension scores as compared to the pre-test scores. In sum, the teaching of academic text cohesive devices does have a significant impact on ESL learners' listening comprehension. Hence, two recommendations for the teaching of listening to ESL learners are: one; to recognize the place of prior knowledge in enhancing comprehension and two; to facilitate listening comprehension through appropriate pre-, while- and post-listening activities.
\end{abstract}

Keywords: academic text, cohesive devices, prior knowledge, listening comprehension 


\section{Introduction}

A factor that could influence listening comprehension is the listeners' background or prior knowledge related to the listening text (Chang \& Read, 2006; Goh, 2000). Vandergrift (2007) noted that ESL listeners would use background knowledge, including on the topic, genre, culture, and other schemas in their long-term memory, to build a conceptual framework against which they interpreted what they heard. Bodie, Imhof and Cooper (2008) reported that other factors specific to a particular listener such as specific knowledge about the topic, world knowledge, memory span, motivation and listening capacity would also interact with aspects of the speaker like interactivity, status, power, role, and the passage objectives to determine listening comprehension. Additionally, it has been suggested that knowledge of grammar may also be a factor affecting listening comprehension (Mecartty, 2000; Hassan, 2000; Ellis 2002; Wingfield, 2003; Kostin, 2004; Vandergrift, 2004; Yanagawa \& Green, 2008). These are concerns which would be impactful on the teaching of listening comprehension.

A number of researches has demonstrated that teaching linguistic knowledge; such as phonology, lexis, syntax, semantics and discourse structure, contributed to learners' listening comprehension (Buck, 2001). It was found that linguistic knowledge, either implicit or explicit, is used as linguistic cues to understand what has been spoken (Anderson, 2009). To further explain this, lexical knowledge is considered to be more explicit, while syntactic or grammatical knowledge are rather implicit. In conjunction to this, a top-down process teaching approach was used to include activities or lessons that required top-down processing to develop the learners' ability to use key words to construct the schema of a discourse or to infer the setting for a text. On the other hand, in classes that used the bottom-up approach, the activities and tasks were aimed to develop bottom-up processing, which helped learners to recognize word and clause divisions, key words and key transitions in a discourse (Richards, 2008). However, Grabe (2004) asserted that the importance of grammar knowledge for listening has not been explored thoroughly although there is a range of research arguing that there might be a strong relation between grammar knowledge and comprehension.

It has been further suggested that teaching specific grammatical structure to ESL students prior to the listening activity could facilitate listening comprehension. (Mecartty, 2000; Hassan, 2000; Ellis 2002; Wingfield, 2003; Kostin, 2004; Vandergrift, 2004; Anderson, 2009). Some researchers claimed that academic text cohesive devices played an essential role in the organization and comprehension of second language texts (Spooren, 2001; Shea, 2009). However, the relationship between teaching academic text cohesive devices and listening comprehension has not been explored excessively. A number of studies have been carried out on uses and functions of academic text cohesive devices with reading, writing and speaking. For example, Degand, Liesbeth and Sanders (2002), investigated the impact of causal cohesive devices on the comprehension of expository texts. In addition, Heino (2011) observed EFL learners' connector usage and comparing it to that of native speakers and Pimsarn (2013) examined the relationship between cohesive devices knowledge and reading comprehension. All the studies have shown that academic text cohesive devices have a fundamental role in facilitating ES/FL learners in understanding the organization and 
subsequently increase comprehension of academic texts. However, the relationship between teaching academic text cohesive devices with listening has not been extensively explored.

\subsection{Statement of Problem}

Second language listening comprehension is a complex process involving prior knowledge sources like linguistic, contextual, and general as well as co-text knowledge (Buck, 2001). Gebhard (2000) stated that prior knowledge is related to our real world experiences. While listening, listeners not only attempt to recognize the linguistic of a text but also try to match the speech with what they already know about the text. In addition, Anderson and Lynch (2000) asserted that because language is used to express culture, lack of prior knowledge specifically on socio-cultural, factual and textual knowledge of the target language could create obstacles to listening comprehension. Thus, it is clearly suggested that prior knowledge plays an important role in comprehending new information through listening.

One of the areas concerning prior knowledge that warrants a more thorough study is on the impact of grammar knowledge on listening comprehension, specifically the effects of having the knowledge of academic text cohesive devices which facilitates text organization on comprehension (Kostin, 2004; Vandergrift, 2004; Yanagawa \& Green, 2008; Anderson, 2009). Fluent text organization provides direction to the reader/listener and shows where the text is going (Shea, 2009). Academic text cohesive devices such as transitional words and phrases signal the meaningful relationships between ideas in the text and eventually help in text comprehension (Brown, 1999). Smit (2006) also asserted that in order to have a coherent interpretation of a lecture, an active listener pays attention to linguistic devices such as cohesive devices that signal structural changes in the organization of the text and indicate when a new direction is taken or when the speaker returns to a previous topic. It is argued that the absence of explicit cohesive devices in a text would pose difficulties in the comprehension process.

Research examining the relationship between knowledge of elements contributing to text cohesion and ESL listening comprehension is sparse, and the findings are mixed. Ying-hui (2006) examined the effects of cohesive devices on ESL listening comprehension and found that higher cohesion in a text is associated with easier test items. Nissan, et al (1996), however, found no effects for cohesion. In addition, some studies concluded that text organization cohesive devices could enhance listening comprehension. Yet, there are some disagreements about the extent to which different types of cohesive devices could be effective (Bloomfield, Wayland, Rhoades, Blodgett, Linck, Ross, 2011). Revesz (2013) also asserted that given the small number of studies which explored the impact of text organization cohesive devices on listening comprehension, more research are required in this area.

Thus, this study aimed to fill this gap by investigating the effect of teaching academic text cohesive devices as a way of activating prior knowledge, on ESL students' listening comprehension test scores.

\subsection{Research Questions}

The study was guided by the following research questions: 
1. Does the input on academic text cohesive devices affect ESL students' listening comprehension test scores?

2. Is there significant improvement in ESL students' listening comprehension test scores in the pre- and post-test?

\section{Literature Review}

Successful listening is determined by the strategies that the listeners use while listening (Richards, 2008). In recent years, the teaching of listening has drawn a greater level of interest and approaches to teaching listening have considerably changed. Research shows that teaching learners how to use strategies provides them with a tool that facilitates the listening process (Mally \& Chamot, 1990; Buck, 2001; Berne 2004; Goh, 2008; Graham \& Macaro, 2008).

Richards (2008) stated that the earlier views of listening considered listening as micro skills like identifying reduced forms of words, cohesive devices and recognizing key words in a text and it is believed that these skills should form the focus of teaching listening. Later views of listening drew on the field of cognitive psychology, which was influenced by the notion of bottom-up and top-down processing and the role of prior knowledge or schema in comprehension and that listening is seen as an interpretive process. However, current views of listening underlines the role of the listener, who is considered an active participant in listening, using strategies to assist, monitor and assess their listening. All these views resulted in different strategies taught in the listening classroom (Richard, 2008).

In addition, Brown (2006) suggested that to teach listening effectively and to improve listening comprehension, an important idea that must be considered in listening classes was to make use of students' prior knowledge. Prior knowledge is structured in schemata, which helps learners understand new experiences. It is considered a part of the cognitive model of language processing which explains that when listening or reading, the information is processed using either or both top-down and bottom-up strategies. Top-down strategy means using prior knowledge and experiences to understand a text while bottom-up processing strategy means using the information about sounds, word meanings, and structure to assemble understanding of what is heard or read (Nunan, 1998, Morely, 2001; Goh, 2002; Miller, 2005; Lynch, 2006; and Brown, 2006). In addition, Brown (2006) and Vandergrift (2007) asserted that learners need both bottom-up and top-down strategies while listening. They must hear some sounds (bottom-up processing), keep them in their working memory for a while to relate them to one another and after that interpret what they have just heard before they hear new things. Meanwhile, listeners use their prior knowledge (top-down processing) to verify meaning in relation to their prior knowledge.

Studies have shown that linguistic knowledge is known to be one of the factors affecting ESL listening comprehension (Nunan, 1998; Mecartty, 2000; Buck, 2001; Goh, 2002; \& Brown, 2006). This is because once students' understanding of grammatical knowledge improved; they would notice the linguistic features in their communicative language input (Ellis 2002). Anderson (2009) also emphasized that knowledge of the English grammar allowed ESL 
students to get at the meaning of a sentence in the comprehension process. Vandergrift (2004) added that ESL students with more linguistic knowledge are thought to retain more information and make better inferences while listening than those without. Hassan (2000) working with 81 Arabic learners, explored the learners' perceptions of English listening comprehension problems, and more than fifty percent of the students state that difficult grammatical structure and unfamiliar words slowed down their listening comprehension. In addition, Murphy (2013) explored the effect of grammatical complexity on 24 language learners' listening comprehension. The results of the study showed that the level of grammatical complexity in spoken sentences led to listening comprehension difficulty. In contrast, Mecartty (2000) asserted that grammatical knowledge did not contribute extensively to either listening or reading comprehension but vocabulary knowledge played the more important role in ESL listening comprehension skill.

To comprehend an academic listening text, a listener could use three schemas while listening which are; linguistic, formal and content schemas (Xiaoli-hui, 2012). Xiaoli-hui (2012) explained that linguistic schema is related to the vocabulary, word phrase and grammar of the language, formal schema refers to the structural characteristics of the text and content schema relates to the background and world knowledge contained in a text (Xiaoli-hui, 2012). Academic text cohesive devices as a part of both linguistic and formal schema (Singhal, 1998) emphasized the important ideas and relationships in language texts (Lorch, 1995). Shea (2009) claimed that the teaching of cohesive devices provided an occasion for students to discuss the types of relationships between propositions. In addition, Sanders and Spooren (2001) stated that many researchers of text processing agreed on the importance of linguistic cues of text structure such as text cohesive devices and discourse markers in text organization. Furthermore, Spooren (2008) pointed out the use of explicit cohesive devices or linking phrases as one way of signalling cohesive relations in language texts. A few studies explored the relation of a type of cohesive device that is discourse marker, with listening comprehension. For example, Thompson (2003) gave special attention to the roles of discourse markers in academic discourse and concluded that the use of discourse markers in authentic lectures at university could help undergraduates form so-called "mental maps" to understand the contents in the whole lecture, especially in talks for academic purposes. Hron et al (1999) also compared two versions of listening scripts with and without discourse markers and found that listeners who have listened to the listening materials with discourse markers significantly performed better than those who have listened to the version without the markers. In addition, Zhang (2012) investigated the impact of teaching discourse markers to English major and non-English major students. He found that teaching cohesive devices could facilitate both English major and non-English major students' listening comprehension. Furthermore, Zhang (2014) conducted a study on 126 Chinese university students to investigate the impact of teaching discourse markers on EFL students' listening comprehension and the relationship between implicit and explicit instruction of these markers. He found that knowledge of discourse markers could improve ESL students' listening comprehension.

Thus, research has demonstrated that prior knowledge of academic text cohesive devices has 
its role in facilitating listening comprehension. However, few studies have been conducted to show the impact of explicit teaching of academic text cohesive devices on listening.

\section{Research Methods}

The data for this study was obtained from one intact group through a pre-test post-test design (Table 3.1). This design used the subjects as their own controls and to reject the need for a control group design (Bell, 2010). Seliger and Shohamy (1989) claimed that the usefulness of this design was that it controlled a number of inessential variables that could impact the homogeneity of subjects when more than one group was involved. To some degree, the design also controlled for attrition or loss of subjects. Since the same group was used for both pre-test and post-test, it did not need to be matched to another group.

Table 1. Research Design of this Study

\begin{tabular}{|c|c|c|c|}
\hline Groups & Pre-test & Treatment & Post-test \\
\hline $\begin{array}{c}\text { One group } \\
(\mathrm{n}=40)\end{array}$ & 0 & $\mathrm{X}$ & 0 \\
& & (Listening Test) & \\
\hline
\end{tabular}

The participants of this study were 40 first year students enrolled in the English for Academic Purposes course at Universiti Malaysia Pahang. There were 19 male and 21 female participants with ages ranging between 19 to 24 years old. Table 2 illustrates the demographic data of the participants.

Table 2. Demographic Data of the Participants

\begin{tabular}{|c|c|c|c|}
\hline \multirow{2}{*}{ Age } & \multicolumn{2}{|c|}{ Gender } & \multirow{2}{*}{ Total } \\
\cline { 2 - 3 } & Male & Female & \\
\hline 19 & 6 & 13 & 19 \\
\hline 20 & 2 & 3 & 5 \\
\hline 21 & 6 & 7 & 13 \\
\hline 22 & 0 & 1 & 1 \\
\hline 23 & 0 & 1 & 1 \\
\hline 24 & 1 & 0 & 1 \\
\hline Total & 15 & 25 & 40 \\
\hline
\end{tabular}


Prior to the treatment, in which participants were taught academic text cohesive devices over a period of 4 weeks, a pre-test was administered. The listening test which was aimed at investigating the effect of treatment on listening comprehension scores was used as the preand post-tests. The lessons, test and marking scheme are further explained as follows:

\subsection{Listening Lessons}

The lessons were conducted in duration of four weeks between the pre- and post-tests. The participants were taught four elements of academic text cohesive devices which were:

Lesson One: Enumerating \& Ordering academic texts cohesive devices, for example First/ Firstly

Lesson Two: Addition and Cause \& Effect academic texts cohesive devices, for example In addition/ Furthermore/ Consequently

Lesson Three: Comparing and Contrasting academic texts cohesive devices, for example In comparison/ Comparatively

Lesson Five: Concluding academic texts cohesive devices for example, In sum/ In short

\subsection{Listening Test}

The test comprised of 3 questions based on 2 academic lectures. The structure of the test was similar to the assessment for English for Academic Communication course listening test. Each question in the listening test assessed the participants' ability to comprehend the content of the listening text. The test format is as follows:

- The first question required the participants to listen to a talk and take notes of what the speaker said. Then they have to complete the notes using appropriate cohesive devices.

- The second question asked the participants to listen to a lecture of two prominent people speaking. The participants have to take down notes on the similarities and differences of the two prominent peoples' lives and put these in a given table.

- The third question required the participants to listen again to the lecture in Question 2 and write a compare and contrast summary about the two prominent people using the notes they took down in Question 2. They were encouraged to use any of the academic text cohesive devices to write the summaries.

\subsection{Listening Comprehension Marking Scheme}

The marking scheme used to score the participants' listening comprehension was adapted from a marking scheme developed by Pandiya (2013). The scheme was aimed at assessing students' academic text listening comprehension. Essentially, the scheme evaluated participants' comprehension through the number of key sentences in the listening texts and the level of cohesion of the written productions using the correct use of academic text cohesive devices. The marking scheme consisted of two components: the first one assessed the number of key sentences written by the participants, which would indicate their comprehension of the listening text. The maximum marks allocated for this was 5 .

The second component evaluated the logical order of the participants' notes and summary 
through their use of appropriate cohesive devices. This was where the researchers could identify the academic text cohesive devices used by the participants, particularly those taught in the lessons and in the listening texts. The marks allocated for this component was also 5. The total mark for the two questions was 20 .

The listening comprehension test was scored by two raters who have had similar teaching experiences and number of years teaching in order to minimise threats to reliability in their rating. They were also given rater training on how to score the listening scripts (McNamara, 2003). Inter-rater reliability analysis was also conducted to determine the reliability between the two raters. When tested using Pearson correlation coefficient, inter-rater reliability was $r$ $=.726$, which signifies a good reliability between the two raters (Mackey \& Gass, 2005).

\section{Findings and Discussion}

\subsection{Listening Comprehension Scores in the Pre-test and Post-test}

Table 3. Pre-test and Post-test Listening Comprehension Scores

\begin{tabular}{|c|c|c|c|c|}
\hline \multirow{2}{*}{$\begin{array}{c}\text { LC Scores/ } \\
\text { 20 marks }\end{array}$} & \multicolumn{2}{|c|}{ Pre-test } & \multicolumn{2}{c|}{ Post-test } \\
\cline { 2 - 5 } & Frequency & $\%$ & Frequency & $\%$ \\
\hline $16-20$ & 0 & 0 & 0 & 0 \\
\hline $11-15$ & 3 & 7.5 & 12 & 30 \\
\hline $6-10$ & 36 & 90 & 26 & 65 \\
\hline $0-5$ & 1 & 2.5 & 2 & 5 \\
\hline Total $(n=40)$ & 40 & 100 & 40 & 100 \\
\hline
\end{tabular}

The total listening score for the listening test was 20 marks. Table 3 shows that in the pre-test most of the participants' scores were in the range between $6-10$ marks; $36(90 \%)$, followed by scores between $11-15 ; 3(7.5 \%)$ and between $0-5 ; 1(2.5 \%)$. None of the participants scored between $16-20$ marks.

On the other hand, there was a marked increase in the number of participants' in the range between $11-15$ marks; $12(30 \%)$ but a decrease in the number of participants in the range between $6-10$ marks; $26(65 \%)$. This was followed by those in the range between $0-5$ marks; 2 (5\%). Again, none of the participants scored between $16-20$ marks. 
Table 4. Comparison of Pre-test and Post-test Listening Comprehension Scores

\begin{tabular}{|c|c|c|c|c|c|}
\hline Marks/20 & $\mathrm{N}$ & Minimum & Maximum & Mean & $\begin{array}{c}\text { Std } \\
\text { Deviation }\end{array}$ \\
\hline Pre-test & 40 & .50 & 12.5 & 8.35 & 2.13 \\
\hline Post-test & 40 & 4 & 14.5 & 9.44 & 2.46 \\
\hline
\end{tabular}

$\mathrm{p}<.05$

The range of marks for the pre-test was between .50 (minimum) to 12.5 (maximum) while in the post-test was 4 (minimum) and 14.5 (maximum) marks (Table 4).

Table 5. Paired samples t-test

\begin{tabular}{|c|c|c|c|c|c|c|c|c|}
\hline \multirow{4}{*}{$\begin{array}{l}\text { pretest } \\
- \\
\text { posttest }\end{array}$} & \multicolumn{5}{|c|}{ Paired Differences } & \multirow[t]{3}{*}{$\mathrm{t}$} & \multirow[t]{3}{*}{$\mathrm{df}$} & \multirow{3}{*}{$\begin{array}{l}\text { Sig. } \\
\text { (2-ta } \\
\text { iled) }\end{array}$} \\
\hline & \multirow[t]{2}{*}{ Mean } & \multirow[t]{2}{*}{$\begin{array}{l}\text { Std. } \\
\text { Deviatio } \\
\mathrm{n}\end{array}$} & \multirow[t]{2}{*}{$\begin{array}{l}\text { Std. } \\
\text { Error } \\
\text { Mean }\end{array}$} & \multicolumn{2}{|c|}{$\begin{array}{l}95 \% \text { Confidence } \\
\text { Interval of the } \\
\text { Difference }\end{array}$} & & & \\
\hline & & & & Lower & Upper & & & \\
\hline & $\begin{array}{l}-1.0875 \\
0\end{array}$ & 2.09972 & $\begin{array}{l}.3319 \\
9\end{array}$ & $\begin{array}{l}-1.7590 \\
2\end{array}$ & -.41598 & -3.276 & $\begin{array}{l}3 \\
9\end{array}$ & .002 \\
\hline
\end{tabular}

A paired-samples t-test was calculated to compare the pre-test and post-test listening comprehension scores. It was also noted that there were differences between the mean scores whereby the mean on the pre-test was $8.35(\mathrm{sd}=2.13)$, and the mean on the post-test was $9.44(\mathrm{sd}=2.46)$. A significant increase from the pre-test to post-test was found $(\mathrm{t})=-3.276, \mathrm{p}$ $<.002)$.

\subsection{Discussion}

The objective of the study was to examine the effect of teaching academic text cohesive devices on ESL students' listening comprehension test scores. Based on the analyses, there was significant improvement in the students' comprehension of the listening texts as indicated in the pre-test and post-test scores. This suggests that teaching the cohesive devices prior to an academic listening activity could facilitate ESL students in comprehending the text better. This could be due to the fact that a coherent text with appropriate use of cohesive devices would make listening easier for ESL learners (Ying-hui, 2006).

In addition, the findings suggested that the treatment given to the learners was effective in enhancing their listening comprehension. When the learners were taught the academic text 
cohesive devices they were able to identify the key sentences and sequence what they have listened to in a logical order through the use of appropriate cohesive devices. This finding is similar to that found by Zhang $(2012 ; 2014)$. It also confirms Thompson's (2003) point of view that the use of cohesive devices in authentic lectures could help students understand the contents of the whole lecture, especially in talks which are for academic purposes. However, no empirical study has been conducted nor has found a significant relationship between teaching academic text cohesive devices and listening comprehension (Zhang, 2014). Hence, this study is significant and timely as it found a significant relationship between teaching academic text cohesive devices and ESL listening comprehension. The findings of this study clearly indicated that teaching academic text cohesive devices did facilitate students' listening comprehension performance and could enhance their listening proficiency to a greater extent.

\section{Limitations of the Study}

A major limitation is the number of participants and groups in the study. Only one intact group was engaged hence the findings may not be as generalizable to the bigger population as compared to an experimental design with a control and an experimental groups. The findings from each group could provide comparisons which a one group design could not provide. Having said that, all measures were taken to ensure the reliability and validity of findings from this study.

\section{Conclusion}

According to Anderson and Lynch (2000), successful listening comprehension takes place when the listener has schematic or prior knowledge and the three areas of prior knowledge relevant to listening comprehension are: linguistic schemata, formal schemata, and content schemata (Xiaoli (2012). In addition, Chang and Read (2006) asserted that pre-listening activities which builds ESL learner's prior knowledge do facilitate listening comprehension. Apart from that while- and post-listening activities such as summarization and note-taking were found to be two major strategies which could help ESL students retain and enhance their comprehension of a listening text (Hutton, 2002; Lin, 2004; Lan, 2008). All of the three elements mentioned: recognizing the role of prior knowledge in listening comprehension, the place of pre-listening activities in building prior knowledge and the utilization of appropriate while- and post-listening activities to improve comprehension were all employed in this study. The results indicated a significant improvement in the ESL learners' listening comprehension performance.

Thus, based on the significant findings this paper concludes with two major recommendations to facilitate and improve the teaching of listening which is a complex (Buck, 2001) but often neglected skill in the ESL classroom (Nunan, 2002). Firstly, listening instructors need to be aware of and build learners' prior knowledge. Brainstorming sessions prior to listening, to gauge the availability of linguistic, formal and/or content schemata relevant to the listening text could be conducted. Secondly, the teaching of listening has to be scaffold to include appropriate pre-, while and post-listening activities. These activities would increase the learners' listening comprehension as they progress through the activities (Rost, 2002). 


\section{Implications for Future Research}

ESL learners spend an average of $50 \%$ of their language learning time on listening and almost $90 \%$ of their learning is received through listening (Morley, 1999). Listening provides the input which supports learning. However, researchers have stated that although listening is at the core of language and learning, it is the least explicitly researched skill of the four language skills (Lynch \& Rost, 2002; Vandergrift, 2007). Thus, it is timely that more language research specifically ES/FL research focused on listening skills. To further the research in this paper a number of improvements could be made. First of all, a stronger experimental design would reap more comparative findings with the existence of experimental-control groups. In addition, richer data could be collected with the addition of qualitative instruments such as interviews to examine students' self-efficacy and perceptions. Finally, repeated replications of the study would enhance the hypothesis that teaching academic text cohesive devices could build ESL learners' prior knowledge and subsequently result in increased listening comprehension.

\section{Acknowledgement}

The research was financed by Universiti Malaysia Pahang Graduate Research Scheme. No. GRS130381.

\section{References}

Berne, J. E. (2004). Listening Comprehension Strategies: A Review of the Literature. Foreign Language Annuals, 37(4), 521-531.

Bloomfield, A., Wayland, S. C., Rhoades, E., Blodgett, A., Linck, J., \& Ross, S. (2011). What makes listening difficult? College Park, MD: University of Maryland Center for Advanced Study of Language. TTO 81434 Technical Report E.3.1.

Bodie, G., Imhof, M., \& Cooper, L. (2008). What Would a Unified Field of Listening Look Like? A Proposal Linking Past Perspectives and Future Endeavors. International Journal of Listening, 22(2), 103-122. doi: 10.1080

Brown, S. (2006). Teaching Listening. Cambridge: Cambridge University Press.

Brown, N. J. (1999). Reading relationships. Boston, MA: Houghton Mifflin.

Buck, G. (2001). Assessing listening. Cambridge: Cambridge University Press.

Chang, C., \& Read, J. (2006). The Effects of Listening Support on the Listening Performance of EFL Learners. TESOL Quarterly, 40. 375-397

Degand, L., \& Sanders, T. (2002). The Impact of Relational Markers on Expository Text Comprehension in L1 and L2. Reading and Writing 15 (7-8), 739-758.

Ellis, R. (2002). The Place of Grammar Instruction in the Second/Foreign Language Curriculum: New Perspectives on Grammar teaching in Second Language Classrooms, 17-34. 
Gebhard, J. (2000). Teaching English as a Foreign or Second Language: A Teacher Self-development and methodology Guide. United States of America: The University of Michigan Press.

Goh, C. (2002). Exploring Listening Comprehension Tactics and their Interaction Patterns. System, 30, 185-206. PII: S0346-251X(02)00004-0

Goh, C. (2008). Metacognitive Instruction for Second Language Listening Development: Theory, Practice and Research Implications. RELC Journal, 39, 7, 8. doi:10.1177/0033688208092184

Grabe, W. (2004). Research on Teaching Reading. Annual Review of Applied Linguistics, 44-69. doi: 10.1017/S0267190504000030

Graham, S., \& Macaro, E. (2008). Strategy Instruction in Listening for Lower Intermediate Learners of French. Language Learning 58(4), 747-783.

Hasan, A. S. (2000). Learners' Perceptions of Listening Comprehension Problems. Language, Culture, and Curriculum, 13 (2), 137-153.

Heino, P. (2010). Adverbial Connectors in Advanced EFL Learners' and Native Speakers' Student Writing. Stockholms Universitet, 10691 Stockholm.

Kostin, I. (2004). Exploring Item Characteristics That Are Related to the Difficulty of TOEFL Dialogue Items. ETC Research report. RP-7-10.

Lan, Y. (2008). Effectiveness Of Note taking, Self-Questioning and Summarizing Strategies on Learning from Diagrams: A Thesis in Educational Psychology. The Pennsylvania State University

Mackey, A., \& Gass, M. S. (2005). Second Language Research: Methodology and Design. Georgetown Universtiy and Michigan State University. Lawrence Erlbaum Associates, Inc., Publishers. ISBN 0-8058-5602-1

Mecartty, F. H. (2000). Lexical and Grammatical Knowledge in Reading and Listening Comprehension by Foreign Language Learners of Spanish. Applied Language Learning, 11(2), 323-348. ISSN:1041-6791.

Miller, L. (2005) Second Language Listening: Theory and Practice. NY: Cambridge University Press.

Morley, J. (2001). Aural comprehension Instruction: Principles and Practices. Teaching English as a Second or Foreign Language, 69-85. Boston: Heinle \& Heinle.

Murphy, E. (2013). The Effect of Working Memory and Syntactic Complexity on Sentence Comprehension. Master Thesis. Brandeis University

Nissan, S., DeVincenzi, F., \& Tang, K. L. (1996). An Analysis of Factors Affecting the Difficulty of Dialogue Items in TOEFL Listening Comprehension. ETS Research Report, 5-37. Princeton, NJ: Educational Testing Service. 
Nunan, D. (1998). Approaches to Teaching Listening in Language Classroom. Proceedings of the 1997 Korea TESOL Conference. Taejon, Korea: KOTESOL.

Pimsarn, P. (2013). The Relationship Between Transitional Word Knowledge And Reading Comprehension Achievement Of First-Year University Students In A Public University In Thailand. Language Institute: Thammasat University.

Revesz, A. (2013). Text Characteristics Of Task Input and Difficulty in Second Language Listening Comprehension. Studies in Second Language Acquisition, 35, 3165 .doi:10.1017/S0272263112000678

Richards, J. C. (2008). Teaching Listening and Speaking: From Theory to Practice. Cambridge University Press, New York. 4,5,6. ISBN-13 978-0-521-95776-2.

Rost, M. (2002). Listening Tasks and Language Acquisition. University of California, Berkeley. JALT2002 AT SHIZUOKA.

Shea, M. (2009). A Corpus-Based Study of Adverbial Connectors in Learner Text. Adverbial Connectors in Learner Texts. MSU Working Papers in SLS 2009 Vol. 1, No. 1.

Smit, T. (2006). Listening Comprehension in Academic Lectures: A Focus on the Role of Discourse Markers. Teaching English to Speakers of Other Languages, University of South Africa.

Spooren, W. (2001). Text Representation as an Interface Between Language and its Users: Linguistic and Psycholinguistic aspects. Amsterdam / Philadelphia: Benjamins.

Thompson, S. E. (2003). Text-structuring Metadiscourse, Intonation and the Signaling of Organization in Academic Lectures. Journal of English for Academic Purposes, 2, 5-20 PII: S1475-1585(02)00036-X.

Vandergrift, L. (2004). Listening to Learn or Learning to Listen? Annual Review of Applied Linguistics. 24, 13-15. doi: 10.1017/S0267290504000017.

Vandergrift, L. (2007). Recent Developments in Second and Foreign Language Listening Comprehension Research. Lang. Teach. 40, 191-210. doi:10.1017/S0261444807004338

Wingfield, A., Peelle, J. E., \& Grossman, M. (2003). Speech Rate and Syntactic Complexity as Multiplicative Cactors in Speech Comprehension by Young and Older Adults. Aging Neuropsychology, and Cognition. 10. doi: 10.1076/10.4.310.28974

Xiaoli-hui. (2012). The Application of Schema Theory in College English Listening Teaching. Theory and Practice in Language Studies, 2, 282-288. doi: 10.4304.

Yanagawa, K., \& Green, A. (2008). To show or Not to Show: The effects of Item Stems and Answer Options on Performance on a Multiple-choice Listening Comprehension Test. System 36, 107-122. doi:10.1016. 
Ying-hui, H. (2006). An Investigation into the Task Features Affecting EFL Listening Comprehension Test Performance. The Asian EFL Journal Quarterly, 8(2), 33-54. ISSN. $1738-1460$.

Zhang, J. (2012). Discourse Markers in College English Listening Instruction: An Empirical Study of Chinese Learners. ELT Vol. 5, No. 3. doi:10.5539.

Zhang, J. (2014). Discourse Markers to College English Listening Proficiency: An Empirical Study of Explicit and Implicit Instruction English Language and Literature Studies. English Language and Literature Studies, Vol. 4, No. 1; 2014. 48. ISSN 1925-4768.

\section{Glossary}

Listening comprehension: Listening comprehension is as a process of receiving what a speaker actually asserts, constructing, representing, negotiating meaning and responding to the speaker (Rost, 2002).

Schemata: Schemata refers to prior knowledge which leads us to expect or predict aspects in our interpretation of a discourse (Brown \& Yule, 1983, p. 248).

Academic text cohesive devices: A single instant of cohesion between a pair of semantically related items" (Innajih, 2007) or cohesive devices (Heino, 2010) or adverbial connectors (Quirk et al. 1985: 631-632) are connective devices that conjoin linguistic units, such as sentences, paragraphs and even larger parts of a text.

\section{Copyright Disclaimer}

Copyright for this article is retained by the author(s), with first publication rights granted to the journal.

This is an open-access article distributed under the terms and conditions of the Creative Commons Attribution license (http://creativecommons.org/licenses/by/3.0/). 